\title{
Meningoencephalitis Associated with SARS-CoV-2 Infection
}

\author{
Gayatri R. Pawar ${ }^{1} \cdot \operatorname{Vinod}$ H. Ratageri ${ }^{1}$ (D) Udaykumar $\mathrm{R}^{1}$ \\ Received: 4 January 2021 / Accepted: 11 February 2021/ Published online: 24 February 2021 \\ (C) Dr. K C Chaudhuri Foundation 2021
}

To the Editor: In the current global pandemic of SARS-CoV2 , children were presenting with varied manifestations, including pediatric inflammatory multisystem syndrome (PIMS) [1] Neurological complications of coronavirus disease 2019 (COVID-19) were increasingly noted in adults and children but not well understood [2]. Though headache and altered taste and smell sensations were known manifestations, serious complications, like meningoencephalitis, Guillain-Barre syndrome and stroke cases were upraising [3].

We describe an 8-y-old male child, presented to us with fever, headache, giddiness, and vomiting of $1 \mathrm{~d}$ duration. Clinical examination revealed normal vitals and signs of meningeal irritation (neck stiffness, Kernig sign positive). Fundus, cranial nerve and motor and sensory system examination were normal at presentation. The other system examinations were unremarkable. Initial lab parameters reported, hemoglobin $(\mathrm{Hb}): 11 \mathrm{~g} / \mathrm{dL}$, total leukocyte count (TLC): 11500/cmm, platelets: $208000 / \mathrm{cmm}$, and cerebrospinal fluid (CSF) analysis revealed 10 lymphoctes/ high-power field (HPF), Protein: $65 \mathrm{mg} / \mathrm{dL}$, glucose: $50 \mathrm{mg} / \mathrm{dL}$ and negative gram stain.

Child was started on intravenous antibiotics for meningitis. On third day of admission, child's condition deteriorated with persistent fever, altered sensorium, and slurred speech. In view of pandemic (no exposure), nasopharyngeal swab and serology testing for COVID-19 were done and found negative reverse transcription polymerase chain reaction (RT-PCR) but positive for immunoglobulin M (IgM) antibody by enzyme-linked immunosorbent assay (ELISA) (VIDAS IgG/IgM by BioMérieux, France). Inflammatory markers were raised (CRP: $50 \mathrm{mg} / \mathrm{L}$, ferritin: $391 \mathrm{ng} / \mathrm{mL}$, D-dimers: $4512 \mathrm{ng} / \mathrm{mL}$, lactate dehydrogenase: > $1000 \mathrm{U} / \mathrm{L}$ ) and computed tomography of brain showed diffuse cerebral edema. Other investigations, chest radiograph, echocardiography, and liver function tests were normal.

Vinod H. Ratageri

ratageri@rediffmail.com

1 Department of Pediatrics, Karnataka Institute of Medical Sciences, Hubli 580021, Karnataka, India
The child was treated with intravenous immunoglobulins (IVIG), mannitol, and other supportive therapy. Rapid recovery was noted with improvement in mentation, meningeal signs, and speech over 48 to $72 \mathrm{~h}$. Steroid was not considered as the child improved with IVIG.

In view of raised inflammatory markers and positive serology and well response to immunoglobulin, PIMS variant was likely in our child. The probable mechanism was immunemediated neuronal damage due to cytokine storm syndrome causing neuronal cell edema, though neuroinvasiveness of coronaviruses is documented in humans [4]. Although seems early, we suggest screening of children presenting with encephalitis for COVID-19.

\section{Declarations}

Conflict of Interest None.

\section{References}

1. Lee PY, Day-Lewis M, Henderson LA, et al. Distinct clinical and immunological features of SARS-CoV-2-induced multisystem inflammatory syndrome in children. J Clin Invest. 2020;130(11): 5942-50.

2. McAbee GN, Brosgol Y, Pavlakis S, Agha R, Gaffoor M. Encephalitis associated with COVID-19 infection in an 11-year-old child. Pediatr Neurol. 2020;109:94.

3. Hafizi F, Kherani S, Shams M. Meningoencephalitis from SARSCoV-2 infection. ID Cases. 2020;21:e00919.

4. Baig AM, Khaleeq A, Ali U, Syeda H. Evidence of the COVID-19 virus targeting the CNS: tissue distribution, host-virus interaction, and proposed neurotropic mechanisms. ACS Chem Neurosci. 2020;11(7):995-8.

Publisher's Note Springer Nature remains neutral with regard to jurisdictional claims in published maps and institutional affiliations. 